\title{
Tenacibaculum lutimaris sp. nov., isolated from a tidal flat in the Yellow Sea, Korea
}

\author{
Jung-Hoon Yoon, So-Jung Kang and Tae-Kwang Oh \\ Korea Research Institute of Bioscience and Biotechnology (KRIBB), PO Box 115, Yusong, \\ Taejon, Korea
}

Correspondence

Jung-Hoon Yoon

jhyoon@kribb.re.kr
The genus Tenacibaculum was proposed by reclassification of two species that had been assigned to the genus Flexibacter, Flexibacter maritimus (Wakabayashi et al., 1986) and Flexibacter ovolyticus (Hansen et al., 1992), as Tenacibaculum maritimum and Tenacibaculum ovolyticum, and with two novel species, Tenacibaculum mesophilum and Tenacibaculum amylolyticum (Suzuki et al., 2001). One further Tenacibaculum species, Tenacibaculum skagerrakense, has been described recently (Frette et al., 2004). The genus Tenacibaculum is characterized chemotaxonomically by having MK- 6 as the predominant menaquinone and by DNA G + C contents of 30.3-35.2 mol\% (Suzuki et al., 2001; Frette et al., 2004). Phylogenetic analyses based on $16 \mathrm{~S}$ rRNA gene sequences showed that the genus is phylogenetically related to the Cytophaga-FlavobacteriumBacteroidetes group (Suzuki et al., 2001; Frette et al., 2004). In this study, we describe four Tenacibaculum-like strains, TF-26 ${ }^{\mathrm{T}}$, TF-28, TF-42 and TF-53, which were isolated from a tidal flat in the Yellow Sea in Korea. The aim of the present work was to determine the taxonomic positions of the four strains by the detailed taxonomic characterization that

Published online ahead of print on 18 November 2004 as DOI 10.1099/ijs.0.63416-0.

The GenBank/EMBL/DDBJ accession numbers for the 16S rRNA gene sequences of strains TF-26 ${ }^{\top}, T F-28, T F-42$ and TF-53 are AY661691, AY661692, AY661693 and AY661694, respectively. combined phenotypic, chemotaxonomic, phylogenetic and genetic analyses.

Bacterial strains were isolated from tidal sediments collected from Daepo Beach in the Yellow Sea, Korea. Strains TF- $26^{\mathrm{T}}$, TF-28, TF-42 and TF-53 were isolated from different specimens by the standard dilution plating technique at $30^{\circ} \mathrm{C}$ on marine agar 2216 (MA; Difco). To investigate their morphological and physiological characteristics, strains TF- $26^{\mathrm{T}}$, TF-28, TF- 42 and TF-53 were routinely cultivated at $30^{\circ} \mathrm{C}$ on MA. Cell morphology was examined by light microscopy (Nikon E600) and transmission electron microscopy (TEM; Philips model CM-20). Presence of flagella was examined by TEM using cells from exponentially growing cultures. Gram reaction was determined using the bioMérieux Gram Stain kit according to the manufacturer's instructions. Gliding motility was determined as described by Bowman (2000). Growth at various temperatures $\left(4-45^{\circ} \mathrm{C}\right)$ was measured on MA. Growth at various $\mathrm{NaCl}$ concentrations was investigated in marine broth 2216 (MB; Difco) or in trypticase soy broth (Difco) lacking $\mathrm{NaCl}$ and in trypticase soy broth. The $\mathrm{pH}$ range for growth was determined in $\mathrm{MB}$ (Difco) that was adjusted to various $\mathrm{pH}$ values ( $\mathrm{pH} 4.5-9.5$ at intervals of $0.5 \mathrm{pH}$ units). Growth under anaerobic conditions was determined after incubation in an anaerobic chamber with MA that had been prepared anaerobically using nitrogen. Catalase and oxidase activities and hydrolysis of casein, starch and 
Tweens 20, 40, 60 and 80 were determined as described by Cowan \& Steel (1965). Hydrolysis of hypoxanthine, tyrosine and xanthine was tested on MA using the substrate concentrations described by Cowan \& Steel (1965). Hydrolysis of aesculin, gelatin and urea and nitrate reduction were studied as described previously (Lanyi, 1987) with the modification that artificial sea water was used for preparation of media. The artificial sea water contained (per litre distilled water) $23.6 \mathrm{~g} \mathrm{NaCl}, 0.64 \mathrm{~g} \mathrm{KCl}, 4.53 \mathrm{~g}$ $\mathrm{MgCl}_{2} \cdot 6 \mathrm{H}_{2} \mathrm{O}, 5.94 \mathrm{~g} \mathrm{MgSO}_{4} \cdot 7 \mathrm{H}_{2} \mathrm{O}$ and $1.3 \mathrm{~g} \mathrm{CaCl}_{2} \cdot 2 \mathrm{H}_{2} \mathrm{O}$ (Bruns et al., 2001). $\mathrm{H}_{2} \mathrm{~S}$ production was tested as described previously (Bruns et al., 2001). Presence of flexirubin pigment was investigated as described by Reichenbach (1992). Congo red adsorption was determined as described by Bernardet et al. (2002). Acid production from carbohydrates was determined as described by Leifson (1963). Growth on several substrates was tested in a basal medium containing $0.2 \mathrm{~g} \mathrm{NaNO}_{3}, 0.2 \mathrm{~g} \mathrm{NH}_{4} \mathrm{Cl}$ and $0.05 \mathrm{~g}$ yeast extract in $1000 \mathrm{ml}$ artificial sea water (Bruns et al., 2001) as described by Suzuki et al. (2001).

Cell biomass for isoprenoid quinone analysis and for DNA extraction was obtained from cultivation for 1-2 days in $\mathrm{MB}$ at $30^{\circ} \mathrm{C}$. Isoprenoid quinones were analysed as described by Komagata \& Suzuki (1987) using reversed-phase HPLC. Chromosomal DNA isolation and purification were performed according to the method described by Yoon et al. (1996), with the exception that ribonuclease T1 was used together with ribonuclease A to minimize the contamination of RNA. For fatty acid methyl ester (FAME) analysis, cell mass of the four strains was harvested from agar plates after incubation for 2 days on MA at $30^{\circ} \mathrm{C}$. The FAMEs were extracted and prepared according to the standard protocol of the MIDI/Hewlett Packard Microbial Identification System (Sasser, 1990). The DNA G + C content was determined by the method of Tamaoka \& Komagata (1984) with a modification that DNA was hydrolysed and the resultant nucleotides were analysed by reversed-phase HPLC.

The 16S rRNA gene was amplified by PCR using two universal primers as described previously (Yoon et al., 1998). Sequencing of the amplified $16 \mathrm{~S}$ rRNA gene and phylogenetic analysis were performed as described by Yoon et al. (2003). DNA-DNA hybridization was performed fluorometrically by the method of Ezaki et al. (1989) using photobiotin-labelled DNA probes and microdilution wells. Hybridization was performed with five replications for each sample. The highest and lowest values obtained in each sample were excluded, and the remaining three values were used to calculate similarity values. The DNA relatedness values quoted are the means of the three values.

Strains TF-26 ${ }^{\mathrm{T}}$, TF-28, TF-42 and TF-53 grew optimally at $30-37^{\circ} \mathrm{C}$ and $\mathrm{pH} 7 \cdot 0-8 \cdot 0$ and in the presence of $2-3 \%$ $(\mathrm{w} / \mathrm{v}) \mathrm{NaCl}$. The four strains were similar in most phenotypic characteristics. Differential characteristics of the four strains were as follows: strains TF- $26^{\mathrm{T}}$ and TF- 53 grew at pH $5 \cdot 0$, but strains TF- 28 and TF- 42 did not; strains TF- $26^{\mathrm{T}}$,
TF- 28 and TF- 42 grew weakly at $40{ }^{\circ} \mathrm{C}$, but strain TF- 53 did not; strains TF-26 ${ }^{\mathrm{T}}$, TF- 28 and TF- 42 did not grow in the presence of greater than $8 \%(\mathrm{w} / \mathrm{v}) \mathrm{NaCl}$, but strain TF-53 did not grow in the presence of greater than $7 \%(\mathrm{w} / \mathrm{v}) \mathrm{NaCl}$; strains TF-28 and TF-42 grew under anaerobic conditions on MA supplemented with nitrate, but strains $\mathrm{TF}-26^{\mathrm{T}}$ and TF-53 did not; strains TF-28 and TF-42 reduced nitrate to nitrogen, but strains TF- $26^{\mathrm{T}}$ and TF-53 did not. Other phenotypic characteristics are shown in Table 1 or given in the species description (see below).

Strains TF-26 $6^{\mathrm{T}}$, TF-28, TF-42 and TF-53 contained menaquinone-6 (MK-6) as the predominant isoprenoid quinone at peak area ratio of approximately $93-97 \%$. The four strains had similar fatty acid profiles that contained large amounts of straight-chain, branched, unsaturated and hydroxy fatty acids; the major components were $\mathrm{C}_{16: 1} \omega 7 \mathrm{c}$ and/or iso- $\mathrm{C}_{15: 0} 2-\mathrm{OH}$, iso- $\mathrm{C}_{15: 0}$, iso- $\mathrm{C}_{16: 0} 3-\mathrm{OH}, \mathrm{C}_{15: 0}$ and iso- $\mathrm{C}_{17: 0} 3-\mathrm{OH}$ (Table 2 ). These fatty acid profiles were similar to those of three Tenacibaculum species analysed in this study (Table 2). There were some differences in the compositions of fatty acids between the four strains and three Tenacibaculum species, particularly between the four strains and T. maritimum JCM $8137^{\mathrm{T}}$ (Table 2). The DNA $\mathrm{G}+\mathrm{C}$ contents of strains TF-26 $6^{\mathrm{T}}, \mathrm{TF}-28, \mathrm{TF}-42$ and TF-53 were $32 \cdot 6,32 \cdot 8,32 \cdot 6$ and $32 \cdot 3 \mathrm{~mol} \%$, respectively.

The 16S rRNA gene sequences of strains TF- $26^{\mathrm{T}}$, TF- 28 , TF-42 and TF-53 determined in this study comprised 1473 nucleotides, representing approximately $96 \%$ of the Escherichia coli 16S rRNA gene sequence. The 16S rRNA gene sequences of strains TF- $26^{\mathrm{T}}, \mathrm{TF}-28$ and TF- 42 were identical. Strain TF-53 showed three nucleotide differences to the other three strains. The phylogenetic trees based on $16 \mathrm{~S}$ rRNA gene sequences showed that strains TF- $26^{\mathrm{T}}$, TF-28, TF-42 and TF-53 fall within the radiation of the cluster comprising Tenacibaculum species (Fig. 1). Strains TF-26 ${ }^{\mathrm{T}}$, TF-28, TF-42 and TF-53 exhibited 16S rRNA gene sequence similarity levels of $97 \cdot 2-98 \cdot 0 \%$ to the type strains of T. mesophilum and T. skagerrakense and of 95.0-97.0\% to the type strains of the other Tenacibaculum species. The four strains exhibited $16 \mathrm{~S}$ rRNA gene sequence similarity levels of $92 \cdot 4-93 \cdot 1 \%$ to Polaribacter species and of less than $89 \cdot 2 \%$ to other species included in the phylogenetic analysis. DNA-DNA hybridization was performed to determine the genomic relatedness among strains TF- $26^{\mathrm{T}}$, TF28, TF- 42 and TF- 53 and between the four novel strains and the type strains of T. mesophilum and T. skagerrakense that showed 16S rRNA gene sequence similarity levels of greater than $97 \%$ to the four strains. Strains TF- $26^{\mathrm{T}}$, TF-28, TF-42 and TF-53 exhibited mean levels of DNA-DNA relatedness of $82-87 \%$, when their DNAs were used individually as labelled DNA probes for cross-hybridization. These values indicate that the four strains are members of the same genomic species. DNA-DNA relatedness levels between the four strains and T. mesophilum DSM $13764^{\mathrm{T}}$ and T. skagerrakense DSM $14836^{\mathrm{T}}$ were in the range of $9-21 \%$. 
Table 1. Differential phenotypic characteristics of Tenacibaculum species

Species: 1, T. lutimaris sp. nov.; 2, T. skagerrakense; 3, T. amylolyticum; 4, T. mesophilum; 5, T. ovolyticum; 6, T. maritimum. Data are from Wakabayashi et al. (1986), Hansen et al. (1992), Suzuki et al. (2001), Frette et al. (2004) and this study. +, Positive; -, negative; W, weakly positive; V, variable reaction; ND, not determined; NG, no growth in the presence of $\mathrm{NaCl}$ only; $n$, number of strains. Data in parentheses are for the type strain. All species are Gram-negative and rod-shaped. All species are positive for catalase, oxidase and degradation of casein.

\begin{tabular}{|c|c|c|c|c|c|c|}
\hline Characteristic & $1(n=4)$ & $2(n=2)$ & $3(n=1)$ & $4(n=4)$ & $5(n=3)$ & $6(n=2)$ \\
\hline \multicolumn{7}{|l|}{ Colony morphology } \\
\hline Shape & $\begin{array}{c}\text { Irregular, } \\
\text { spreading edge }\end{array}$ & $\begin{array}{c}\text { Circular, } \\
\text { spreading edge }\end{array}$ & $\begin{array}{c}\text { Circular, } \\
\text { spreading edge }\end{array}$ & $\begin{array}{c}\text { Irregular, } \\
\text { spreading edge }\end{array}$ & Regular edge & Uneven edge \\
\hline Colour & Pale yellow & Bright yellow & Yellow & Yellow & Pale yellow & Pale yellow \\
\hline Spherical cells & Very rare & Frequent & Very rare & Very rare & ND & $+^{\star}$ \\
\hline Temperature range $\left({ }^{\circ} \mathrm{C}\right)$ & $10-39$ & $10-40$ & $20-35$ & $15-40$ & $4-25$ & $15-34$ \\
\hline Optimal temperature $\left({ }^{\circ} \mathrm{C}\right)$ & $30-37$ & $25-37$ & $27-30$ & $28-35$ & ND & 30 \\
\hline \multicolumn{7}{|l|}{ Growth on: } \\
\hline L-Proline & - & + & + & + & - & - \\
\hline L-Glutamate & - & + & + & + & - & $\mathrm{W}$ \\
\hline L-Leucine & - & $\mathrm{W}$ & - & - & - & - \\
\hline \multicolumn{7}{|l|}{ Degradation of: } \\
\hline Starch & - & + & + & - & - & - \\
\hline Gelatin & + & ND & + & + & + & $+\dagger$ \\
\hline Tween 80 & - & - & + & + & + & + \\
\hline Nitrate reduction & $\mathrm{V}(-)$ & + & $\mathrm{w}$ & - & + & + \\
\hline DNA G $+C$ content $(\mathrm{mol} \%)$ & $32 \cdot 3-32 \cdot 8$ & $35 \cdot 2$ & $30 \cdot 9$ & $31 \cdot 6-32 \cdot 0$ & $30 \cdot 3-32 \cdot 0$ & $31 \cdot 3-32 \cdot 5$ \\
\hline
\end{tabular}

${ }^{*}$ Spherical cells may appear in old cultures (Wakabayashi et al., 1986; Bernardet et al., 2002).

$\dagger$ Data from Wakabayashi et al. (1986); different result was obtained by Suzuki et al. (2001).

In the phylogenetic trees, inferred from comparison of 16S rRNA gene sequences, the four strains were phylogenetically affiliated to the genus Tenacibaculum (Fig. 1). The predominant isoprenoid quinone type was in agreement with the result of phylogenetic classification based on 16S rRNA gene sequences. The menaquinone (MK-6) detected in the four strains was the same as that for the genus Tenacibaculum (Suzuki et al., 2001). The fatty acid profiles of the four strains were similar to those of the type strains of the three Tenacibaculum species that were analysed in this study (Table 2). These fatty acid profiles were similar to those of Polaribacter species, some Cellulophaga species and Flavobacterium aquatile (Gosink et al., 1998; Bernardet et al., 1996) but were distinguished from those of some other phylogenetically related taxa, although the observation may be caused by different experimental conditions. Hydroxy fatty acids were major components in the four strains and Tenacibaculum species, while they were not detected or were minor components in the genera Psychroserpens and Gelidibacter (Bowman et al., 1997). The fatty acid iso- $\mathrm{C}_{13: 0}$, which was a minor component in the four strains and Tenacibaculum species, was one of the major components in the genus Coenonia (Vandamme et al., 1999). The four strains were similar phylogenetically and genetically as well as phenotypically. Strains TF- $26^{\mathrm{T}}$, TF-28, TF-42 and TF-53 were distinguished from the five Tenacibaculum species by differences in some phenotypic properties as shown in Table 1. The genetic distinctiveness, together with $16 \mathrm{~S}$ rRNA gene sequence similarity data, were enough to categorize the four strains as a species that is distinct from the five current Tenacibaculum species (Wayne et al., 1987; Stackebrandt \& Goebel, 1994). Therefore, on the basis of the data presented, strains TF-26 ${ }^{\mathrm{T}}$, TF-28, TF-42 and TF-53 should be classified in the genus Tenacibaculum as members of a novel species, for which the name Tenacibaculum lutimaris sp. nov. is proposed. 
Table 2. Cellular fatty acid compositions (\%) of strains TF-26 ${ }^{\top}, T F-28, T F-42$ and TF-53 and the type strains of three Tenacibaculum species

Strains: 1, strain TF-26 ${ }^{\mathrm{T}}$; 2, strain TF-28; 3, strain TF-42; 4, strain TF-53; 5, T. skagerrakense DSM 14836 ${ }^{\mathrm{T}}$; 6, T. mesophilum DSM 13764 ${ }^{\mathrm{T}}$; 7, T. maritimum JCM $8137^{\mathrm{T}}$. Fatty acids that represented less than $0 \cdot 5 \%$ in all strains were omitted.

\begin{tabular}{|c|c|c|c|c|c|c|c|}
\hline Fatty acid & 1 & 2 & 3 & 4 & 5 & 6 & 7 \\
\hline \multicolumn{8}{|l|}{ Straight-chain fatty acids } \\
\hline $\mathrm{C}_{15: 0}$ & $8 \cdot 9$ & $10 \cdot 0$ & $8 \cdot 3$ & $8 \cdot 5$ & $4 \cdot 9$ & $3 \cdot 6$ & $2 \cdot 9$ \\
\hline $\mathrm{C}_{16: 0}$ & $0 \cdot 6$ & $0 \cdot 4$ & $0 \cdot 6$ & $0 \cdot 6$ & $0 \cdot 6$ & $0 \cdot 7$ & $0 \cdot 3$ \\
\hline $\mathrm{C}_{18: 0}$ & - & - & - & - & - & - & $1 \cdot 4$ \\
\hline \multicolumn{8}{|l|}{ Branched fatty acids } \\
\hline iso- $\mathrm{C}_{13: 0}$ & $0 \cdot 7$ & $0 \cdot 5$ & $0 \cdot 6$ & $0 \cdot 5$ & $0 \cdot 2$ & $0 \cdot 8$ & $1 \cdot 8$ \\
\hline iso- $\mathrm{C}_{14: 0}$ & $1 \cdot 7$ & $1 \cdot 1$ & $1 \cdot 5$ & $1 \cdot 2$ & $0 \cdot 9$ & $0 \cdot 8$ & $0 \cdot 8$ \\
\hline iso- $\mathrm{C}_{15: 0}$ & $17 \cdot 2$ & $17 \cdot 1$ & $17 \cdot 8$ & $14 \cdot 9$ & $9 \cdot 5$ & $13 \cdot 2$ & $16 \cdot 8$ \\
\hline iso- $\mathrm{C}_{15: 1}$ & $5 \cdot 3$ & $5 \cdot 2$ & $4 \cdot 4$ & $5 \cdot 1$ & $8 \cdot 2$ & $7 \cdot 1$ & $7 \cdot 6$ \\
\hline anteiso- $\mathrm{C}_{15: 0}$ & $0 \cdot 7$ & $0 \cdot 9$ & $1 \cdot 1$ & $0 \cdot 8$ & - & $1 \cdot 1$ & $0 \cdot 8$ \\
\hline iso- $\mathrm{C}_{16: 0}$ & $3 \cdot 8$ & $2 \cdot 6$ & $3 \cdot 0$ & $3 \cdot 3$ & $1 \cdot 3$ & $1 \cdot 7$ & $0 \cdot 3$ \\
\hline iso- $\mathrm{C}_{16: 1}$ & $1 \cdot 7$ & $1 \cdot 7$ & $1 \cdot 7$ & $1 \cdot 5$ & $1 \cdot 7$ & $0 \cdot 8$ & - \\
\hline iso- $\mathrm{C}_{17: 1} \omega 9 c$ & $0 \cdot 4$ & $0 \cdot 5$ & $0 \cdot 4$ & $0 \cdot 4$ & - & $0 \cdot 6$ & - \\
\hline \multicolumn{8}{|l|}{ Unsaturated fatty acids } \\
\hline $\mathrm{C}_{15: 1} \omega 6 c$ & $4 \cdot 2$ & $5 \cdot 3$ & $4 \cdot 4$ & $4 \cdot 3$ & - & $1 \cdot 6$ & $2 \cdot 2$ \\
\hline $\mathrm{C}_{17: 1} \omega 6 c$ & $1 \cdot 5$ & $2 \cdot 1$ & $1 \cdot 6$ & $1 \cdot 8$ & $1 \cdot 2$ & $0 \cdot 9$ & $0 \cdot 3$ \\
\hline \multicolumn{8}{|l|}{ Hydroxy fatty acids } \\
\hline $\mathrm{C}_{15: 0} 2-\mathrm{OH}$ & $1 \cdot 2$ & $1 \cdot 2$ & $1 \cdot 4$ & $1 \cdot 5$ & $2 \cdot 5$ & $1 \cdot 1$ & $1 \cdot 1$ \\
\hline $\mathrm{C}_{15: 0} 3-\mathrm{OH}$ & $3 \cdot 4$ & $4 \cdot 1$ & $3 \cdot 9$ & $3 \cdot 8$ & $8 \cdot 6$ & $2 \cdot 9$ & $3 \cdot 8$ \\
\hline iso- $\mathrm{C}_{15: 0} 3-\mathrm{OH}$ & $4 \cdot 6$ & $5 \cdot 2$ & $5 \cdot 7$ & $4 \cdot 5$ & $7 \cdot 8$ & $8 \cdot 0$ & $19 \cdot 8$ \\
\hline $\mathrm{C}_{16: 0} 3-\mathrm{OH}$ & $1 \cdot 3$ & $1 \cdot 3$ & $1 \cdot 7$ & $1 \cdot 8$ & $2 \cdot 1$ & $3 \cdot 2$ & $1 \cdot 5$ \\
\hline iso- $\mathrm{C}_{16: 0} 3-\mathrm{OH}$ & $12 \cdot 8$ & $11 \cdot 3$ & $13 \cdot 0$ & $13 \cdot 0$ & $12 \cdot 2$ & $9 \cdot 0$ & $5 \cdot 0$ \\
\hline $\mathrm{C}_{17: 0} 2-\mathrm{OH}$ & $0 \cdot 2$ & $0 \cdot 3$ & $0 \cdot 3$ & $0 \cdot 4$ & - & $0 \cdot 8$ & - \\
\hline $\mathrm{C}_{17: 0} 3-\mathrm{OH}$ & $0 \cdot 9$ & $1 \cdot 2$ & $1 \cdot 1$ & $1 \cdot 2$ & $2 \cdot 5$ & $0 \cdot 7$ & $0 \cdot 6$ \\
\hline iso- $\mathrm{C}_{17: 0} 3-\mathrm{OH}$ & $8 \cdot 4$ & $8 \cdot 8$ & $8 \cdot 6$ & $9 \cdot 0$ & $11 \cdot 7$ & $14 \cdot 9$ & $13 \cdot 7$ \\
\hline Unknown fatty acid $\left(\mathrm{ECL}^{*} 16 \cdot 582\right)$ & $0 \cdot 7$ & $0 \cdot 6$ & $0 \cdot 4$ & $0 \cdot 7$ & $0 \cdot 6$ & $1 \cdot 0$ & $1 \cdot 0$ \\
\hline Summed feature $3 \dagger$ & $18 \cdot 1$ & $18 \cdot 1$ & $17 \cdot 4$ & $19 \cdot 7$ & $22 \cdot 5$ & $24 \cdot 4$ & $17 \cdot 9$ \\
\hline
\end{tabular}

${ }^{\star}$ ECL, Equivalent chain-length.

$\uparrow$ Summed feature represent groups of two or three fatty acids that could not be separated by GLC with the MIDI system. Summed feature 3 contained $\mathrm{C}_{16: 1} \omega 7 c$ and/or iso- $\mathrm{C}_{15: 0} 2-\mathrm{OH}$.

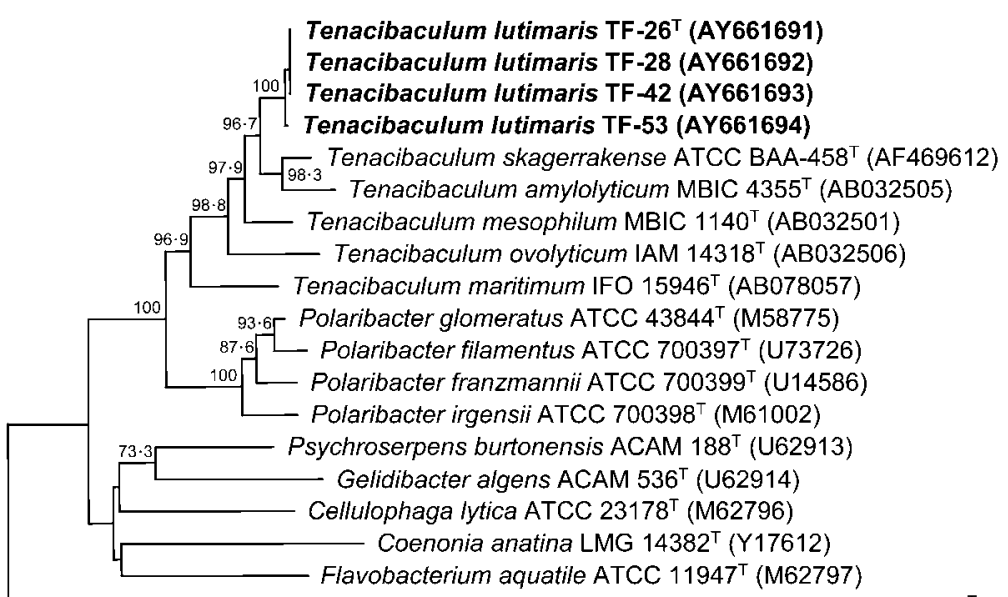

Cytophaga hutchinsonii ATCC $33406^{\top}$ (M58768) $\underline{0.01}$
Fig. 1. Neighbour-joining phylogenetic tree based on 16S rRNA gene sequences showing the positions of strains TF- $26^{\top}$, TF-28, TF-42 and TF-53 and some other related taxa. The numbers on the branches indicate the bootstrap value of 1000 resamplings (greater than $50 \%$ ). Bar, 0.01 substitution per nucleotide position. 


\section{Description of Tenacibaculum lutimaris sp. nov.}

Tenacibaculum lutimaris (lu.ti.ma'ris. L. n. lutum mud; L. gen. n. maris of the sea, marine; N.L. gen. n. lutimaris of a marine mud).

Cells are Gram-negative and non-flagellated. Motile by means of gliding. Colonies are irregular, smooth, glistening and pale yellow in colour on MA at $30^{\circ} \mathrm{C}$. Adherence of colonies to MA is observed. Growth occurs at 10 and $39^{\circ} \mathrm{C}$ with an optimum temperature of $30-37^{\circ} \mathrm{C}$; growth does not occur at $4{ }^{\circ} \mathrm{C}$ or above $41^{\circ} \mathrm{C}$. Optimal $\mathrm{pH}$ for growth is between $7 \cdot 0$ and $8 \cdot 0$; no growth is observed at $\mathrm{pH} 4 \cdot 5$. Optimal growth occurs in the presence of $2-3 \%(\mathrm{w} / \mathrm{v})$ $\mathrm{NaCl}$; growth does not occur in the absence of $\mathrm{NaCl}$. Flexirubin-type pigments are absent. Tyrosine is hydrolysed. Aesculin, hypoxanthine, Tweens 20, 40 and 60, xanthine and urea are not hydrolysed. $\mathrm{H}_{2} \mathrm{~S}$ is not produced. Growth under anaerobic conditions does not occur on MA. Growth under anaerobic conditions on MA supplemented with nitrate is variable (negative for type strain). Growth occurs on peptone and tryptone as the sole carbon and nitrogen sources, but does not occur on D-glucose. No acid is produced from L-arabinose, D-cellobiose, D-fructose, Dgalactose, D-glucose, lactose, maltose, D-mannose, melibiose, D-melezitose, D-raffinose, L-rhamnose, D-ribose, sucrose, D-trehalose, D-xylose, adonitol, D-sorbitol, myoinositol or D-mannitol. Predominant menaquinone is MK-6. Major fatty acids are $\mathrm{C}_{16: 1} \omega 7 c$ and/or iso- $\mathrm{C}_{15: 0}$ $2-\mathrm{OH}$, iso- $\mathrm{C}_{15: 0}$, iso- $\mathrm{C}_{16: 0} 3-\mathrm{OH}, \mathrm{C}_{15: 0}$ and iso- $\mathrm{C}_{17: 0}$ $3-\mathrm{OH}$. DNA $\mathrm{G}+\mathrm{C}$ content is $32 \cdot 3-32 \cdot 8 \mathrm{~mol} \%$. Other phenotypic properties are given in Table 1 .

The type strain, TF $-26^{\mathrm{T}}\left(=\mathrm{KCTC} 12302^{\mathrm{T}}=\mathrm{DSM} 16505^{\mathrm{T}}\right)$, was isolated from a tidal flat on Daepo Beach in the Yellow Sea, Korea. Reference strains are TF-28, TF-42 and TF-53.

\section{Acknowledgements}

This work was supported by $21 \mathrm{C}$ Frontier Program of Microbial Genomics and Applications (grant MG02-0401-001-1-0-0) from the Ministry of Science and Technology (MOST) of the Republic of Korea.

\section{References}

Bernardet, J.-F., Segers, P., Vancanneyt, M., Berthe, F., Kersters, K. \& Vandamme, P. (1996). Cutting a Gordian knot: emended classification and description of the genus Flavobacterium, emended description of the family Flavobacteriaceae, and proposal of Flavobacterium hydatis nom. nov. (basonym, Cytophaga aquatilis Strohl and Tait 1978). Int J Syst Bacteriol 46, 128-148.

Bernardet, J.-F., Nakagawa, Y. \& Holmes, B. (2002). Proposed minimal standards for describing new taxa of the family Flavobacteriaceae and emended description of the family. Int J Syst Evol Microbiol 52, 1049-1070.

Bowman, J. P. (2000). Description of Cellulophaga algicola sp. nov., isolated from the surfaces of Antarctic algae, and reclassification of Cytophaga uliginosa (ZoBell and Upham 1944) Reichenbach 1989 as Cellulophaga uliginosa comb. nov. Int J Syst Evol Microbiol 50, 1861-1868.
Bowman, J. P., McCammon, S. A., Brown, J. L., Nichols, P. D. \& McMeekin, T. A. (1997). Psychroserpens burtonensis gen. nov., sp. nov., and Gelidibacter algens gen. nov., sp. nov., psychrophilic bacteria isolated from Antarctic lacustrine and sea ice habitats. Int J Syst Bacteriol 47, 670-677.

Bruns, A., Rohde, M. \& Berthe-Corti, L. (2001). Muricauda ruestringensis gen. nov., sp. nov., a facultatively anaerobic, appendaged bacterium from German North Sea intertidal sediment. Int J Syst Evol Microbiol 51, 1997-2006.

Cowan, S. T. \& Steel, K. J. (1965). Manual for the Identification of Medical Bacteria. London: Cambridge University Press.

Ezaki, T., Hashimoto, Y. \& Yabuuchi, E. (1989). Fluorometric deoxyribonucleic acid-deoxyribonucleic acid hybridization in microdilution wells as an alternative to membrane filter hybridization in which radioisotopes are used to determine genetic relatedness among bacterial strains. Int J Syst Bacteriol 39, 224-229.

Frette, L., Jørgensen, N. O. G., Irming, H. \& Kroer, N. (2004). Tenacibaculum skagerrakense sp. nov., a marine bacterium isolated from the pelagic zone in Skagerrak, Denmark. Int J Syst Evol Microbiol 54, 519-524.

Gosink, J. J., Woese, C. R. \& Staley, J. T. (1998). Polaribacter gen. nov., with three new species, $P$. irgensii sp. nov., $P$. franzmannii sp. nov. and $P$. filamentus sp. nov., gas vacuolated polar marine bacteria of the Cytophaga-Flavobacterium-Bacteroides group and reclassification of 'Flectobacillus glomeratus' as Polaribacter glomeratus comb. nov. Int J Syst Bacteriol 48, 223-235.

Hansen, G. H., Bergh, Ø., Michaelsen, J. \& Knappskog, D. (1992). Flexibacter ovolyticus sp. nov., a pathogen of eggs and larvae of Atlantic halibut, Hippoglossus hippoglossus L. Int J Syst Bacteriol 42, 451-458.

Komagata, K. \& Suzuki, K.-I. (1987). Lipid and cell wall analysis in bacterial systematics. Methods Microbiol 19, 161-207.

Lanyi, B. (1987). Classical and rapid identification methods for medically important bacteria. Methods Microbiol 19, 1-67.

Leifson, E. (1963). Determination of carbohydrate metabolism of marine bacteria. J Bacteriol 85, 1183-1184.

Reichenbach, H. (1992). The order Cytophagales. In The Prokaryotes, a Handbook on the Biology of Bacteria: Ecophysiology, Isolation, Identification, Applications, 2nd edn, pp. 3631-3675. Edited by A. Balows, H. G. Trüper, M. Dworkin, W. Harder \& K. H. Schleifer. New York: Springer.

Sasser, M. (1990). Identification of Bacteria by Gas Chromatography of Cellular Fatty Acids. Newark, DE: MIDI.

Stackebrandt, E. \& Goebel, B. M. (1994). Taxonomic note: a place for DNA-DNA reassociation and 16S rRNA sequence analysis in the present species definition in bacteriology. Int J Syst Bacteriol 44, 846-849.

Suzuki, M., Nakagawa, Y., Harayama, S. \& Yamamoto, S. (2001). Phylogenetic analysis and taxonomic study of marine Cytophagalike bacteria: proposal for Tenacibaculum gen. nov. with Tenacibaculum maritimum comb. nov. and Tenacibaculum ovolyticum comb. nov., and description of Tenacibaculum mesophilum sp. nov. and Tenacibaculum amylolyticum sp. nov. Int J Syst Evol Microbiol 51, 1639-1652.

Tamaoka, J. \& Komagata, K. (1984). Determination of DNA base composition by reverse-phase high-performance liquid chromatography. FEMS Microbiol Lett 25, 125-128.

Vandamme, P., Vancanneyt, M., Segers, P., Ryll, M., Köhler, B., Ludwig, W. \& Hinz, K.-H. (1999). Coenonia anatina gen. nov., sp. nov., a novel bacterium associated with respiratory disease in ducks and geese. Int J Syst Bacteriol 49, 867-874. 
Wakabayashi, H., Hikida, M. \& Masumura, K. (1986). Flexibacter maritimus sp. nov., a pathogen of marine fishes. Int J Syst Bacteriol 36, 396-398.

Wayne, L. G., Brenner, D. J., Colwell, R. R. \& 9 other authors (1987). International Committee on Systematic Bacteriology. Report of the ad hoc committee on reconciliation of approaches to bacterial systematics. Int J Syst Bacteriol 37, 463-464.

Yoon, J.-H., Kim, H., Kim, S.-B., Kim, H.-J., Kim, W. Y., Lee, S. T., Goodfellow, M. \& Park, Y.-H. (1996). Identification of
Saccharomonospora strains by the use of genomic DNA fragments and rRNA gene probes. Int J Syst Bacteriol 46, 502-505.

Yoon, J.-H., Lee, S. T. \& Park, Y.-H. (1998). Inter- and intraspecific phylogenetic analysis of the genus Nocardioides and related taxa based on 16S rDNA sequences. Int J Syst Bacteriol 48, 187-194.

Yoon, J.-H., Kim, I.-G., Shin, D.-Y., Kang, K. H. \& Park, Y.-H. (2003). Microbulbifer salipaludis sp. nov., a moderate halophile isolated from a Korean salt marsh. Int J Syst Evol Microbiol 53, $53-57$. 